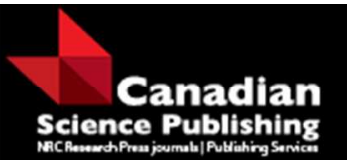

Canadian Journal of Forest Research Revue canadienne de recherche forestière

\title{
Variability in aboveground carbon driven by slope aspect and curvature in an eastern deciduous forest, USA
}

\begin{tabular}{|r|l|}
\hline Journal: & Canadian Journal of Forest Research \\
\hline Manuscript ID & cjfr-2016-0147.R1 \\
\hline Danuscript Type: & Article \\
\hline Complete List of Authors: & $\begin{array}{l}\text { Smith, Lauren; Pennsylvania State University Huck Institutes of the Life } \\
\text { Sciences, Ecosystem Science and Management; Oregon State University, } \\
\text { Fisheries and Wildlife } \\
\text { Eissenstat, David; Pennsylvania State University Huck Institutes of the Life } \\
\text { Sciences, Ecosystem Science and Management } \\
\text { Kaye, Margot; Pennsylvania State University Huck Institutes of the Life } \\
\text { Sciences, Ecosystem Science and Management }\end{array}$ \\
\hline Keyword: & aboveground net primary productivity, litter fall, basal area, Quercus, Acer \\
\hline & \multicolumn{2}{|c}{} \\
\hline
\end{tabular}

\section{SCHOLARONE ${ }^{m}$}

Manuscripts 
1 Variability in aboveground carbon driven by slope aspect and curvature in an eastern

2 deciduous forest, USA.

3

4 Lauren A. Smith*

5236 Forest Resource Building

6 Department of Ecosystem Science and Management and Inter-College Graduate Degree Program

7 in Ecology

8 The Pennsylvania State University, State College, PA, 16802, USA

9 las586@psu.edu

10

11 David M. Eissenstat

$12 \quad 201$ Forest Resource Building

13 Department of Ecosystem Science and Management and Inter-College Graduate Degree Program

14 in Ecology

15 The Pennsylvania State University, State College, PA, 16802, USA

16 dme9@psu.edu, 814-863-3371

17

18 Margot W. Kaye

19303 Forest Resource Building

20 Department of Ecosystem Science and Management and Inter-College Graduate Degree Program

21 in Ecology

22 The Pennsylvania State University, State College, PA, 16802, USA

23 mwk12@psu.edu, 814-865-4841

24

*Corresponding author, Current Address: 2121 S. $1^{\text {st }}$ Street, OSU Hermiston Agricultural Research and Extension Center, Hermiston, OR 97330, USA, lauren.smith@oregonstate.edu, $541-567-6337$ 


\section{Abstract}

In forested ecosystems, topography and tree species contribute to spatial variability in carbon (C) dynamics through differential rates of $\mathrm{C}$ uptake and storage; therefore, estimates of species-specific and spatial variability in $\mathrm{C}$ can strengthen ecosystem budgets. To produce such estimates we deconstructed watershed-scale $\mathrm{C}$ and component pools (e.g. wood biomass, litter) and fluxes at a fine scale using a small mixed deciduous forest catchment to determine the variation due to topographic position and species. Factors affecting fluxes included aspect, slope curvature, tree species contributions, and litter production. Annual $\mathrm{C}$ uptake into wood varied

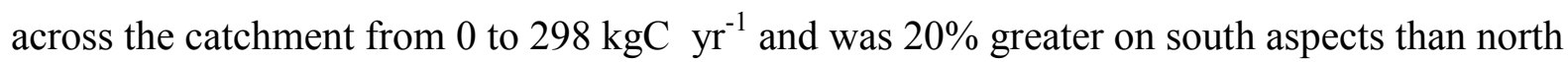
and $33 \%$ greater in swales than non-swale slopes. Out of $>20$ tree species found in the forest canopy of the catchment, highest $\mathrm{C}$ uptake in woody biomass was measured in Q. rubra growing in swales, followed by $Q$. prinus growing on the south aspect, with the lowest aboveground wood increment measured in Pinus at higher elevations on non-swale slopes. Quercus leaf litter moved from where it dropped into litter traps to where it settled on the forest floor, shifting the location of litter $\mathrm{C}$ inputs to the soil. Local variation in aboveground $\mathrm{C}$ rivals regional variation across regions and has the potential to introduce error when scaling $\mathrm{C}$ measures from points to landscapes.

$\underline{\text { Key Words: }}$, aboveground net primary productivity, basal area, litter fall, Quercus, Acer, Carya 


\section{$\underline{\text { 1. Introduction }}$}

Carbon $(\mathrm{C})$ storage is a valued ecosystem service driven largely by the composition and

ecosystems with measures of net primary productivity (NPP) (Waring et al. 1998, Fahey et al. 2005, Siccama et al. 2007, Richardson et al. 2009); however, few have examined how tree species-specific contributions to forest productivity differ spatially and as a function of topography (but see Yanai et al. 2012a). Defining species-specific contributions to forest productivity across topographic positions can reduce uncertainty of aboveground $\mathrm{C}$ budgets and identify landscape positions that play important roles in aboveground carbon uptake and storage. Forested landscapes are often represented by single productivity values calculated from ground measurements or eddy covariance towers that provide estimated values for the non-swale surface around the tower (Stoy et al. 2013). However, spatial variability in components of productivity at a fine scale (e.g. $\mathrm{m}^{2}$ to hectares) can exceed variability documented across thousands of kilometers (Houghton 2005), as well as variability measured through time (Yanai et al. 2012a). If forest productivity varies across complex topography in a non-linear fashion, then single average values may not represent cumulative productivity across a landscape and measures of $\mathrm{C}$ stock and fluxes at diverse positions are needed.

Spatial patterns of forest $\mathrm{C}$ dynamics can be influenced by topographic variability in abiotic resources such as incoming solar radiation, soil moisture, and soil nutrients. The influence of solar radiation and aspect on tree growth depends on latitude and elevation, with higher sun exposure benefiting forests that are temperature-limited and stressing species near the warm edge of their distribution (Way and Oren 2010, Sharma et al. 2011). Additional environmental variability occurs due to slope curvatures like swales, which are concave, low- 
71 lying areas (Jin and Brantley 2011). Swales can be favorable microenvironments for vegetation

72 due to deep soils and increased water availability, but are also disturbed by seasonal water run

73 off that could reduce establishment of vegetation due to surface scouring. Heterogeneity in the

74 growing environments between swales and non-swale (planar or convex) slopes at fine-scales

$75\left(<100 \mathrm{~m}^{2}\right)$ and between aspects at slightly larger scales $\left(<1000 \mathrm{~m}^{2}\right)$ could drive spatial variability

76 in forest $\mathrm{C}$ dynamics across a watershed $\left(>1000 \mathrm{~m}^{2}\right)$.

77 Topographic variability in $\mathrm{C}$ dynamics in a deciduous forest, especially resulting soil

78 carbon, is further influenced by annual leaf litter production and redistribution. Spatial

79 distribution of leaf litter can affect plant establishment, reduce soil temperature fluctuation, and

80 change the biochemical composition of the soil (Facelli and Picket 1991, Xiong and Nilsson

81 1999, Bartuszevige et al. 2007). Estimates of leaf production from litter traps captures the

82 biomass dropping from the canopy of a deciduous forest, but may not capture where that leaf

83 litter settles on the forest floor. Litter redistribution in a watershed is regulated by aspect and

84 microtopographic depressions such as swales, understory vegetation type, and fallen logs

85 (Orndorff and Lang 1981, Lee et al. 1999). In forested watersheds, large amounts of litter can be

86 transported, including across slopes, by strong wind and heavy rain (Lee et al. 1999). Leaf litter

87 moving downslope or by wind can become trapped in low-lying swales where it eventually

88 settles and decomposes. Litter movement also depends on species composition. Litter-fall

89 shadow, the distance leaves and litter fall to the forest floor from the tree, differs among species

90 due to leaf shape, crown morphology, and timing of leaf fall (Ferrari and Sugita 1996). In a

91 study focusing on leaf litter redistribution in an Allegheny Plateau watershed, Quercus spp.

92 leaves were more likely to move after they hit the ground than non-Quercus spp., mainly due to 
93 their large leaf surface area (Boerner and Kooser 1989). Thus, variability in leaf litter movement

94 among species could be an important factor influencing spatial patterns in $\mathrm{C}$ dynamics.

Our study focused on spatial $\mathrm{C}$ distribution of aboveground carbon uptake and storage

96 across a small watershed catchment that hosts a temperate deciduous forest with over 20 canopy-

97 tree species and topographic diversity created by north and south aspects and swales and non-

98 swale slopes. Our main objectives were to: 1) Determine tree species contributions to forest

99 productivity in the catchment; 2) Quantify spatial patterns in aboveground C by comparing basal

100 area and $\mathrm{C}$ uptake to wood between north and south aspects and on swales and non-swale slopes;

101 and 3) Identify tree genera with the potential to influence soil $\mathrm{C}$ by determining spatial

102 mismatches between leaf production and litter inputs to the forest floor. We predicted that the

103 main contributors to forest productivity would be the dominant tree species in the study

104 catchment, primarily oaks (Quercus spp.). We hypothesized that higher wood C uptake would

105 be found on the south facing aspect compared to north due to a positive response to warmer

106 temperatures of oaks at the north end of their distribution. We also hypothesized that

107 aboveground $\mathrm{C}$ uptake on non-swales would be greater than those on swales due to higher stand

108 basal area and density, but individual tree growth would be faster in swales due to rich soils,

109 increased water availability, and lower competition among trees.

110 2. Methods

111 2. 1 Study Site

112 Our study took place in the small forested watershed catchment of the Susquehanna Shale

113 Hills Critical Zone Observatory (Shale Hills). Shale Hills is located in Huntingdon County,

114 Pennsylvania and is an 8.53 hectare catchment on Rose Hill shale bedrock covered by a 110+

115 year old humid temperate forest. The mean annual temperature is $11^{\circ} \mathrm{C}$ and the annual 
116 precipitation is $900 \mathrm{~mm}$ (Naithani et al. 2013). The catchment has north- and south-facing

117 aspects, with an elevation change of 60 meters from the lowest point to the highest point (240-

$118300 \mathrm{~m}$ above sea level) and seven large swales distributed across the catchment that are

119 surrounded by non-swale slopes (Fig. 1). Swales were identified as low lying areas in the

120 catchment created by seasonal runoff with convergent flow, and non-swale hill-slopes identified

121 by areas with non-convergent flow (Andrews et al. 2011). There are 23 large-stature tree species

122 in the catchment including oaks (Quercus prinus L. syn., Q. rubra L., Q. alba L., Q. velutina

123 Lam.), maples (Acer saccharum Marsh., A. rubrum L.), hickories (Carya tomentosa (Lam.)

124 Nutt., C. glabra (P. Mill.) Sweet, C. ovata (P. Mill.) K. Koch, C. cordiformis (Wangenh.) K.

125 Koch), Eastern hemlock (Tsuga canadensis (L.) Carr.), and pines (Pinus virginiana P. Mill., P.

126 strobus L.). Land use history of the forest over the past two centuries was homogenous across

127 the catchment and representative for the region. Tree harvesting started in the mid-1800s, when

128 land area may have been cleared for pasture (the catchment was never tilled), and ending by the

129 1930s when the last tree harvesting occurred (Wubbels 2010). Many canopy trees established

130 between 1850-1950, as documented from age sampling with radial cores from 110 trees from

131 eight dominant species ranging in diameter from 10-75 cm (unpublished tree core data).

$132 \quad 2.2$ Field measurements to estimate aboveground wood $C$

133 In fall 2008 each tree within the catchment with diameter-at-breast-height (DBH) over 20

$134 \mathrm{~cm}$ was tagged, identified to species, DBH recorded, and GPS coordinates mapped using ESRI

135 ArcMap Desktop 10.2 geostatistical analyst (ESRI, 2013). In fall 2012 DBHs of all living

136 tagged trees were re-measured (Eissenstat and Kaye 2012; Kaye et al. 2015).

$137 \quad 2.3$ Field measurements to estimate leaf litter $C$ 
139 litter dynamics on the forest floor. Leaf litter was collected in 35 traps with $0.152 \mathrm{~m}^{2}$ area and 140 suspended $0.5 \mathrm{~m}$ off the ground (Yanai et al. 2012a). Traps were located on five elevation 141 transects, including locations in swales and on non-swale slopes. During 2011 and 2012 leaf

142 litter was collected once a week from September $1^{\text {st }}$ to December $1^{\text {st }}$ (when the deciduous trees 143 stopped dropping leaves in the litter traps).

145 species composition of leaf litter in litter traps, and species composition of litter on the forest

146 floor. Litter was collected once every two weeks in 2012 from forest floor plots located adjacent

147 to the 35 litter traps. Forest floor plots were the same area as litter traps but not elevated from 148 the forest floor and were marked in the corners by stakes to allow for litter movement. Litter 149 was collected within the plot boundary off of the forest floor by hand.

All litter was dried at $57^{\circ} \mathrm{C}$ for a minimum of $24 \mathrm{hrs}$ then sorted into species and

151 weighed. C contributed from litter was analyzed for $\%$ foliar $\mathrm{C}$ using a subset of leaves from six 152 dominant species. Samples were ground, $\sim 3 \mathrm{~g}$ were massed, and analyzed for $\%$ foliar C.

153 Percent $\mathrm{C}$ was used to convert litter mass to grams C. The six species analyzed were $A$. rubrum, 154 A. saccharum, F. americana, Q. prinus, Q. rubra and T. canadensis; biomass of other species 155 was assumed to have $48 \% \mathrm{C}$ content (Bowden et al. 1992). 2.4 Data Analysis Carbon components of the ecosystem were estimated from field measurements. Basal 158 area $(\mathrm{BA})\left(\mathrm{m}^{2}\right)$ per tree was calculated with the DBH data measured in 2012. The 2008 and 2012 159 tree DBH measurements were used to estimate woody biomass excluding foliage in grams $(\mathrm{g})$ for 160 each tree. Aboveground biomass including bark and stem and branch wood, was estimated per 
161 tree with the following five species group allometric equations that encompass all the species in

162 the catchment: soft maple/birch, mixed hardwood, hard maple/oak/hickory/beech, true

163 fir/hemlock, and pine (Jenkins et al. 2003). Species group allometric equations were used rather

164 than species-specific equations as $10 \%$ of the stems fell outside of the DBH range limits for the 165 species-specific equations and because species-specific equations are often site specific and may 166 not represent our study area (Jenkins et al. 2004). Carbon stored annually in aboveground wood 167 increment (AGWI) was calculated by subtracting 2008 biomass from 2012 biomass and dividing

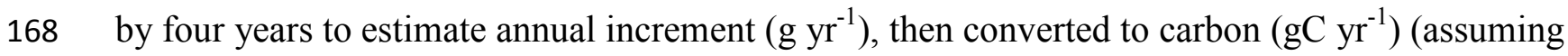
169 wood biomass is $48 \% \mathrm{C}$ (Bowden et al. 1992)).

To visualize $\mathrm{C}$ spatial variability across the catchment, estimates of $\mathrm{AGWI}\left(\mathrm{gC} \mathrm{yr}^{-1}\right)$ were

171 used to make a wall-to-wall interpolated map using ESRI ArcMap Desktop 10.3 geostatistical

172 analyst (ESRI, 2015). To normalize the data, a log scale +1 was used for the AGWI

173 interpolation. All of the trees measured were used and placed on the map with corresponding

174 biomass $(\mathrm{kgC})$ estimates calculated using species group biometric equations as described above.

175 Ordinary kriging was found to be the best interpolation method via summary statistics of a 176 diagnostic cross-validation comparison.

Data from the four Carya species (C. glabra, C. tomentosa, C. ovata, and C. cordiformis)

178 were grouped together for analysis due to 1) possible errors in field identification of C. glabra 179 and C. tomentosa and 2) leaf litter from Carya ovata, cordiformis, and glabra, could not be 180 separated reliably by species. The majority of the 333 Carya trees were either C. glabra $(\sim 125$ 181 trees) or C. tomentosa ( $\sim 175$ trees), both of which are found on mesic to xeric slopes, upland 182 areas, and have similar ecology and growth forms suggesting that their contribution to watershed 183 carbon are comparable and can be grouped for analysis (Burns and Honkala 1990). However, 
184 185

grouping Carya species together prevented species-level comparisons such as those done for all other genera.

BA and AGWI data were analyzed with three approaches. First, total density, total BA, and total AGWI were calculated on an area basis (density: stems $\mathrm{ha}^{-1}, \mathrm{BA}: \mathrm{m}^{2} \mathrm{ha}^{-1}$, AGWI: gC $\mathrm{ha}^{-1} \mathrm{yr}^{-1}$ ) by summing the number of stems, BA, and AGWI of all trees and dividing by the 8.53 ha area of the catchment. Similar calculations were made for the four topographic positions of south aspect, north aspect, non-swale slopes, and swale by dividing by the area of the catchment that falls within that position $(3.85,4.68,6.64$, and 1.89 ha respectively) producing total values for each topographic position. Secondly, BA and AGWI were estimated on a species basis for specific areas (north versus south aspects; swale versus non-swale slopes) and species comparisons were made with two-sample paired t-tests. Thirdly, comparisons of average BA

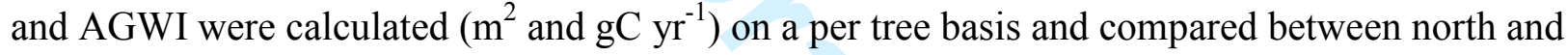
south aspects and swale and non-swale surfaces with two-sample t-tests assuming equal variance for trees from all species together and for trees from the four dominant species. Comparisons were significant at the $\alpha=0.05$ and Bonferroni corrections were made for multiple comparisons. Using the litter trap area and percent $\mathrm{C}$ content, litterfall was scaled up to landscape units $\left(\mathrm{gC} \mathrm{m}^{-2} \mathrm{yr}^{-1}\right)$. A simple linear regression was performed to test the relationship between species basal area in the catchment and average annual leaf litter production. ANPP of each species in the catchment was estimated by adding AGWI $\left(\mathrm{gC} \mathrm{m}^{-2} \mathrm{yr}^{-1}\right)$ and leaf litter production $\left(\mathrm{gC} \mathrm{m}^{-2} \mathrm{yr}^{-}\right.$

$\left.{ }^{1}\right)$. Spatial comparisons of ANPP were not done because of the mismatch in spatial resolution of stem growth data (inventory with $2000+$ trees) with that of leaf litter data (35 traps at individual points in the catchment). We compared the litter mass estimated from litter traps with that estimated by forest floor data collections by dominant genera (Carya, Acer, Quercus, and Pinus) 
207 instead of by species because not all species were collected in both the traps and floor plots. We

208 tested the relationship between total leaf litter production by species $\left(\mathrm{gC} \mathrm{m}^{-1} \mathrm{yr}^{-1}\right)$ measured in

209 litter traps with that measured in forest floor plots using a linear regression. R studio statistical

210 software was used for all analyses (R Development Core Team, 2013).

2112.5 Limitations

There are limitations to our estimates of aboveground $\mathrm{C}$ in the Shale Hills CZO

213 catchment. Trees $<20 \mathrm{~cm} \mathrm{DBH}$ and trees that reached $20 \mathrm{~cm}$ within the four year study period

214 were not included in the measurements, and are therefore not included in the density, BA, and

215 AGWI estimates. This could lead to greater underestimates of carbon for late-successional

216 species such as Acer saccharum that have more small stems than Quercus species that dominate

217 the canopy. From additional vegetation sampling in the catchment we estimate that stems 10-20

$218 \mathrm{~cm} \mathrm{DBH}$ comprise $9 \%$ of BA and $36 \%$ of stem for all trees $<10 \mathrm{~cm} \mathrm{DBH.} \mathrm{ANPP} \mathrm{is}$

219 underestimated by not accounting for coarse woody debris, nutrient and $\mathrm{C}$ leaching, or herbivory

220 (Pregitzer and Burton 1991, Clark et al. 2001, Goodale et al. 2002). In addition, approximately

22140 trees died within the four year time period that were not included in our analysis, further

222 underestimating ANPP and AGWI for the catchment. Understory vegetation was not included in

223 basal area or AGWI measurements; however, other studies have found that understory vegetation

224 contributed 1\% or less to forest carbon stocks (Turner et al. 1995, Goodale et al. 2002).

$225 \quad 2.6$ Uncertainty Analysis

226 The amount of error surrounding ecosystem nutrient budget estimates is rarely reported

227 but is important as the use of allometric equations introduces uncertainty into the estimates

228 (Yanai et al. 2010, Yanai et al. 2012b). We discuss the amount of uncertainty of our

229 aboveground $\mathrm{C}$ estimates following Harmon et al. 2015 guidelines that suggest reporting four 
230 sources of uncertainty including: measurement uncertainty, sampling uncertainty, model

231 prediction uncertainty, and model selection uncertainty. We estimated measurement uncertainty

232 of $1 \%$ for tree DBH measurements based on values reported by Harmon et al. 2015. There is no

233 sampling uncertainty because we measured all of the trees in the catchment, and in fact our

234 results can provide estimates of sampling uncertainty for other studies based on spatial

235 variability in aboveground $\mathrm{C}$ quantified here. Prediction uncertainty for the models requires

236 large biomass datasets that are independent of the allometric equation parameterization, which

237 are not available (Jenkins et al. 2003), and were therefore unable to include that source of

238 uncertainty in our assessment. Model selection uncertainty was approximated for the biomass

239 equations with a simple comparison of AGWI estimates based on the species group allometric

240 equations that we used in our analysis and AGWI calculated from species-specific equations

241 from Jenkins et al. 2004. Species-specific equations developed at sites closest to our study area

242 were selected for the analysis. AGWI estimates varied $9 \%$ between the two types of allometric

243 models, which can be considered a rough estimate of uncertainty in our model selection. Based

244 on our calculations and values available from other studies, we made a conservative estimate of

$24510 \%$ uncertainty by summing the three sources of uncertainty because they could be additive.

246 3. Results

247 A total of 2031 trees (stems) from 23 species were measured for estimates of carbon

248 pools and fluxes across the catchment. In the 8.53 ha catchment area, total ANPP was $443 \mathrm{gC} \mathrm{m}^{-}$

$2492^{2} \mathrm{yr}^{-1}$, with $\sim 66 \%$ stored in woody $\mathrm{C}$ increment and $\sim 33 \%$ in leaf litter production (Table 1 ). $Q$.

250 rubra, Q. prinus, and Q. alba were the top contributors to ANPP, stem density, basal area,

251 AGWI, and leaf litter production (Table 1), with Carya species and A. saccharum also making

252 major contributions. 
Aboveground biomass and aboveground wood increment (AWGI) varied across the catchment (Fig. 2). Biomass of individual trees ranged from 18 to $2587 \mathrm{~kg} \mathrm{C}$. Areas with trees of higher biomass were located along the base of the north aspect, especially in swales (Fig. 2).

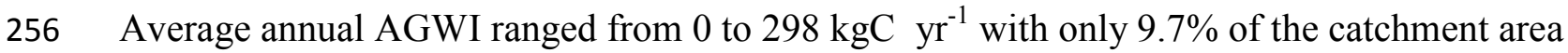

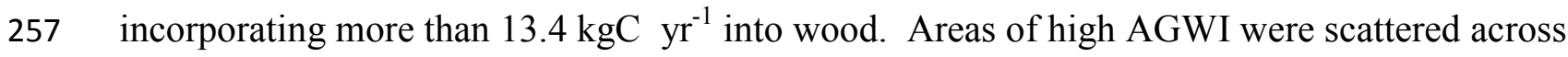
258 most of the catchment, except along the upper north aspect, where tree density and biomass were 259 low (Fig. 2).

On an area basis, forests on south and north aspects had similar species richness, stem 261 density, total biomass, and total basal area, but the forest on south aspects had $20 \%$ greater total 262 AGWI (Table 2). On a species basis, most dominant species that had trees present on both the 263 north and south slopes had higher per species total basal area and/or total AGWI on south aspect 264 compared to north aspect (e.g. Q. alba, Carya spp.), except Q. rubra that had higher basal area 265 and AGWI on the north aspect (Fig. 3). When comparing average AGWI on a tree basis, south 266 aspect trees had on average 16\% higher AGWI than north aspect trees (two-sample t-test, $\mathrm{df}=$ $2672024, P<0.0001$ ) but BA was not different (two-sample t-test, $\mathrm{df}=2029, P=0.29)($ Table 2 ). 268 Of the four dominant species in the catchment, AGWI per tree was greater on south 269 aspects than north for $Q$. prinus (two-sample t-test, $\mathrm{df}=550, P<0.001$ ), but not $Q$. alba (two270 sample t-test, $\mathrm{df}=274, P=0.829), Q$. rubra (two-sample t-test, $\mathrm{df}=277, P=0.885)$, and $A$.

271 saccharum, (two-sample t-test, $\mathrm{df}=127, P=0.311$ ). BA per tree was greater on south aspect than

272 north for $Q$. prinus (two-sample t-test, $\mathrm{df}=552, P=0.007$ ), greater on north aspects than south 273 for $Q$. rubra (two-sample t-test, $\mathrm{df}=278, P=0.008$ ), and not different between aspects for $A$. 274 saccharum (two-sample t-test, $\mathrm{df}=128, P=0.91$ ) and $Q$. alba (two-sample t-test, $\mathrm{df}=275, P$ $275=0.412)$. 
Forests on swales had the lowest tree density and the highest biomass, BA, and AGWI

277

278

279

280

281

282

283

284

285

286

287

288

289

290

291

292

293

294

295

296

297

298

compared to non-swales, as well as $\mathrm{N}$ and $\mathrm{S}$ aspects (Table 2). Comparing swales and non-swale areas, stem density was slightly lower in swales (5\%), total biomass higher $(10 \%)$, total basal area slightly higher in swales (4\%), and total AGWI 33\% higher in swales than non-swale (Table 2). Both total basal area and AGWI of dominant species (e.g. Q. prinus, Q. rubra, Q. alba) were higher in swales than non-swale slopes (Fig. 3).

Comparing measurements between swales and planer slopes, average BA and AGWI per tree of all species on swales were greater than on non-swale slopes. Average AGWI per tree was $41 \%$ higher in swales than on non-swale slopes (two-sample t-test, $\mathrm{df}=2024, P=<0.0001$ ) and average BA per tree was $9 \%$ higher in swales than on non-swale slopes (two-sample t-test, $\mathrm{df}=$ 2029, $P=0.005$ ) (Table 2). For the four dominant tree species, $Q$. rubra, $Q$. prinus, $Q$. alba, and A. saccharum, AGWI per tree was not significantly different between non-swale slopes and swales (two-sample t-test, $\mathrm{df}=277, P=0.291$, two-sample t-test, $\mathrm{df}=550, P=0.212$, twosample t-test, $\mathrm{df}=274, P=0.588$, two-sample t-test, $\mathrm{df}=127, P=0.251$, respectively) (Table 2 ). BA per tree was significantly higher in swales than non-swale slopes for Q. rubra and Q. prinus (two-sample t-test, $\mathrm{df}=278, \mathrm{p}=0.045$, two-sample t-test, $\mathrm{df}=552, P=0.007$, respectively); however, it was not different for $Q$. alba and $A$. saccharum (two-sample t-test, df =275, $P=$ 0.356, two-sample t-test, $\mathrm{df}=128, P=0.369$, respectively) (Table 2).

Relative species contributions of leaf litter $\mathrm{C}$ in the catchment reflected stem biomass and AGWI patterns. Species basal area was positively correlated with species annual leaf litter (simple linear regression, $P<0.0001, R^{2}=0.852$ ) (Fig. 4). The three Quercus species $(Q . r u b r a$, Q. prinus, Q. alba) produced the largest amount of leaf litter, followed by Carya and Acer species (Table 1). Total litter production in litter traps and forest floor litter was significantly 
299 correlated for Carya and Acer $(P<0.01$, Fig. 5) but not significant for Quercus $(P=0.703)$ and 300 Pinus $(P=0.675$, Fig. 5). Percent carbon in leaf litter of the six species analyzed for foliar C 301 varied from $43 \%$ in A. rubrum to $50 \%$ in T. canadensis (A. rubrum $43.0 \pm 3.3 \mathrm{SE}$; A. saccharum $30245.6 \pm 0.1 ;$ Q. rubra $45.8 \pm 0.2$; Q. prinus $45.8 \pm 0.3 ;$ F. americana $48.1 \pm 0.6$; T. canadensis, $303 \quad 50.2 \pm 0.73)$

\section{4. Discussion}

Deconstructing aboveground carbon in a small watershed catchment illustrates the heterogeneity in its components across topography and among species. Within the watershed we measured differences between annual carbon tree storage (Fig. 2) comparable to estimates across large geographic regions, and aboveground $\mathrm{C}$ pools and uptake were consistently highest in swales and on the south aspect. Large differences in wood C uptake in eastern deciduous forests have been measured at sites across a broad geographic area spanning the Appalachian region, with sites in Tennessee having nearly $70 \%$ greater $\mathrm{C}$ uptake in wood than a site in Massachusetts 312 (220 $\mathrm{gC} \mathrm{ha}^{-1} \mathrm{yr}^{-1}$ in $\mathrm{TN}$ and $130 \mathrm{gC} \mathrm{ha}^{-1} \mathrm{yr}^{-1}$ in MA; Curtis et al. 2002). The single catchment comparison presented here points to the potential for small-scale variability in $\mathrm{C}$ uptake to rival

314 large-scale ranges. Aboveground $\mathrm{C}$ uptake in woody biomass is a major component of forest 315 ANPP, accounting for up to $70 \%$ of net ecosystem productivity (NEP) (Brown and Schroeder 316 1999, Barford et al. 2001), and a large increase in wood-carbon uptake in swales compared to 317 non-swales likely translates to greater NEP in swales. Spatial variability in aboveground C such 318 as those observed in this study highlights the value of examining how forest $\mathrm{C}$ can change across 319 the landscape and among species to alter $\mathrm{C}$ pools and fluxes. 
322 north aspect, where many large hemlocks and oaks could have access to deep soils and water.

323 Areas with low annual $\mathrm{C}$ storage $\left(<2 \mathrm{kgC} \mathrm{m}^{-2} \mathrm{yr}^{-1}\right)$ were located on the north aspect at higher

324 elevations on non-swale slopes. These areas had a lower density of trees and included pines and

325 maples that were sequestering small amounts of $\mathrm{C}$ annually.

Differences in annual C storage in wood growth between topographic positions

327 underscore the importance of plot-level measures occurring on variable slopes and aspects to 328 avoid over or under-estimating $\mathrm{C}$ uptake for extrapolation to broader areas. Aspect-driven 329 variability in forest productivity may have some predictability based on the forest community, 330 and the effect of solar radiation on aspect microclimate. Warmer conditions on south aspects (30 $331 \mathrm{~W} \mathrm{~m}^{-2}$ greater on average, unpublished data) in the Shale Hills catchment may drive higher 332 productivity because the resident oak-hickory forests are at the northern end of their distribution 333 and temperature-limited. Higher productivity in the form of more wood C uptake on the south 334 aspect indicates that the growing environment is more suited to the oak-hickory forests than the 335 north aspect. This relationship was supported by species-specific growth rates (discussed in 336 detail below), because forests of species with more southern distributions were more productive 337 on the south aspect, while those with more northern distributions (e.g. Q. rubra, T. canadensis) 338 were more productive on the north aspect. Spatial differences in $\mathrm{C}$ were also driven by slope curvature. Tree density in swales was 340 lower, trees were larger on average, and grew faster than trees on non-swale slopes. We 341 hypothesize that lower density of trees in swales due to seasonal disturbances from the 342 concentration of surface water runoff in swales (Lin et al. 2006) could be responsible in part for 343 the higher per-tree basal area and wood growth in swales because of lower competition for 344 resources among trees. The larger size and greater growth of trees in swales are likely due to 
345 higher resource availability from deep soils. High resource availability may lead to dominance

346 of some trees over others, but as with aspect comparisons we did not directly measure resource

347 availability in swales compared to non-swale slopes. However, vegetated swales have been

348 known to trap more nutrients from surface runoff and have even been used to control

349 contaminants (Yousef et al. 1987). A confounding factor in slope curvature comparisons is that

350 more of the south aspect falls within swales (Fig. 1), and the south aspect had higher C uptake in

351 wood than the north aspect. Overall, the magnitude of influence of slope curvature in

352 aboveground $\mathrm{C}$ was more than that of aspect, with swales consistently having greater

353 aboveground $\mathrm{C}$ stock and uptake than non-swale slopes. Furthermore, the magnitude of spatial

354 variability in $\mathrm{C}$ measures exceeded the estimated uncertainty of $10 \%$ approximated for our

355 analysis, although our conservative uncertainty analysis likely underestimated overall

356 uncertainty.

357 4.1 Species contributions to aboveground C

Each of the 23 dominant tree species in Shale Hills had unique patterns of $\mathrm{C}$ uptake and

359 storage across topographic positions, highlighting the functional diversity of trees in eastern

360 deciduous forests and potential resilience to environmental change. Catchment ANPP was

361 dominated by the genus Quercus, which contributed $71 \%$ of the catchment total. Among the

362 three dominant oak species, $Q$. prinus had approximately twice as many stems in the catchment,

363 indicating the productivity of that species was driven by many smaller stems compared to fewer

364 larger stems of Q. rubra and Q. alba. Stems of A. saccharum and A. rubrum are forest canopy

365 sub-dominants that generally grow at slower rates than canopy dominant trees such as the oak

366 species in this forest; however, A. saccharum and A. rubrum contribute $14 \%$ of the total leaf

367 litter to the catchment. The conifer species T.canadensis and P. strobus together accounted for 
$5 \%$ of ANPP, which is underestimated because leaf litter collection was restricted to Oct-Dec and these evergreen species can lose needles throughout the year. We attempted to evaluate this bias by estimating the annual change in foliar biomass for each species using foliage component allometric equations. The foliage component allometric equations overestimated the amount of foliage we collected annually from $T$. canadensis by approximately $20 \%$ and underestimated the amount of foliage we collected from $P$. strobus by approximately $60 \%$. These results indicate that we may have missed $20 \%$ of the T. canadensis foliage during collection; but collected more than one year's foliage growth of $P$. strobus during our three months of collection.

Spatial heterogeneity in $\mathrm{C}$ across the catchment was associated with differential productivity among species. The greatest hotspot of $\mathrm{C}$ uptake in wood was driven by high productivity of $Q$. rubra trees growing on the north aspect at the base of swale, near the valley bottom (Fig. 2). Among species, the topographic position with highest $\mathrm{C}$ uptake varied (Fig. 6). Productivity of Q. rubra was greatest in swales and north aspects and Q. prinus was greater on the south aspect and within swales. Q. alba seemed minimally sensitive to slope curvature, but had greater productivity on the south aspect. Among the less dominant species, greater productivity occurred at various topographic positions, such as on the south aspect for $Q$. velutina, Fraxinus americana, A. saccharum, and P. strobus, while T. canadensis showed higher C uptake on the north aspect.

Species suitability to topographic positions is generally related to their geographic distributions. Among oak species, Q. rubra has a more northern distribution and reaches greater growth rates in cooler conditions, as was seen in Shale Hills. In contrast, Q. prinus is a more southern species tolerant of warm temperatures and lower water availability. Tsuga canadensis has a broad latitudinal range from Georgia to Canada, but is mostly restricted to cool valley 
391 bottoms and ridge tops in its southern extent, and is a component of mixed northern hardwood

392 stands. Its optimal growth on the north aspect reflects its preference to cooler climates. Our

393 results suggest that climate-envelope models of shifting species distribution could capture and

394 predict small-scale patterns in species suitability, as seen in Shale Hills.

\subsection{Litter movement}

Discrepancies between species in the litter traps and forest floor plots document

397 horizontal movement of leaf litter as it drops. Of the four genera analyzed, Quercus and Pinus

398 showed no correlation between litter collected in the elevated litter traps and the forest floor,

399 indicating that litter moves laterally after dropping from the canopy. Movement, or litter

400 redistribution, suggests that litter nutrient inputs to the forest floor may differ across the

401 landscape, altering productivity estimates and forest floor dynamics such as moisture retention

402 (Kreye et al. 2013). Quercus dominated aboveground C of this catchment and produced a

403 majority of the leaf litter. Given that litter accounts for one third of ANPP, miscalculations of

404 ANPP could be large when horizontal litter redistribution occurs in dominant species. Unlike

405 Quercus and Pinus, the quantity of Carya and Acer litter in the traps and forest floor were

406 correlated, suggesting their litter is not moving laterally. Lack of lateral movement by litter may

407 be due to smaller leaf or leaflet surface areas, which would reduce litter movement by wind and

408 water.

Less litter was collected from forest floor plots than litter traps for each of the four

410 genera, which could be explained by three mechanisms: 1) decomposition, 2) mass loss due to

411 soil fauna, and 3) litter movement. We collected forest floor litter every two weeks throughout

412 our collection period to decrease the chance of litter decomposition. Previous studies have found

413 that maples and oaks lose 55 and $40 \%$ of their mass, respectively, throughout the year in litter 
414 bags, excluding soil fauna (McClaugherty et al. 1985). However, when soil fauna was not

415 excluded from the litter, maples and oaks lost $92-97 \%$ and $63-70 \%$ of their mass in one year,

416 respectively (Holdsworth et al. 2012). Earth worms are present at Shale Hills and were not

417 excluded from this study. This may have had an effect on the total biomass collected from the

418 forest floor plots during the collection period; however, frequent collection of litter from the

419 forest floor plots should have decreased the chance of litter losses to macroinvertebrates. Litter

420 movement has been quantified in other watersheds by tracing movements temporally and

421 identifying areas of sources and sinks (Boerner and Kooser 1989, Fahnestock et al. 2000). We

422 cannot conclude how much litter is redistributed annually from this study as we only studied

423 litter movement for four months out of the year (Sept to Dec); however, litter has been

424 documented redistributing throughout the entire year. One study in an Allegheny Plateau

425 watershed found that largest quantity of litter was redistributed from January to April (Boerner

426 and Kooser 1989). Based on frequent litter collection and information from other studies, we

427 attribute differences in litter between traps and the forest floor to litter movement, although we

428 did not document where litter actually settles in the watershed.

\section{5. Summary}

Aboveground carbon in the 8-ha oak-dominated watershed catchment varied based on

431 aspect, species contributions, and litter production. While catchment values of C uptake into

432 wood were similar to those measured in other eastern deciduous forests, within-catchment values

433 were heterogeneous, ranging widely from 0 to $248 \mathrm{kgC} \mathrm{yr}^{-1}$. An estimate of $10 \%$ uncertainty in

434 our analysis indicates that the magnitude of differences observed across the watershed exceeds

435 the magnitude of analysis uncertainty, although our approximations were conservative. Annual

436 C uptake into woody biomass was $20 \%$ greater on south aspects than north aspects and $33 \%$ 
437 greater in swales than non-swales. Annual carbon storage was $40 \%$ higher in trees in swales

438 than non-swales. We recommend considering spatial heterogeneity when estimating $\mathrm{C}$ pools and

439 fluxes in complex topographical watersheds, in addition to reporting uncertainty in ecosystem

440 budgets (Yanai et al. 2010, Yanai et al. 2012b, Harmon et al. 2015). In light of projected climate

441 change, spatial patterns of carbon uptake by species may be of interest for forest $\mathrm{C}$ uptake

442 planning and accounting. Among the 20+ canopy tree species in the catchment, those in the

443 genus Quercus dominated aboveground C, specifically Q. rubra and Q. prinus. The highest

444 measured rates of carbon uptake in wood were measured in Q. rubra growing in swales,

445 followed by $Q$. prinus growing on the south aspect. Quercus leaf litter moved laterally from the

446 litter traps to where it settled on the forest floor, highlighting a limitation of using litter traps for

447 spatial analysis of litter contributions to forest floor carbon. Finally, patterns of aboveground

448 carbon in the catchment suggests a level of resilience of the forest ecosystem to environmental

449 change due to the diversity of $\mathrm{C}$ cycling strategies found among tree species and topographic

450 positions.

$451 \quad$ 6. Acknowledgements

452 We conducted this research at the Penn State Stone Valley Forest, which is funded by the Penn

453 State College of Agriculture Sciences, Department of Ecosystem Science and Management, and

454 managed by the staff of the Forestlands Management Office. We would like to thank Jason Kaye,

455 Katie Gaines, Tom Adams, Jenna Mitchell, Jared Prokopchak, Rachel Hoh, Sarah Wurzbacher,

456 Christy Rollinson, and Julie Weitzman. Financial and logistical support and data were provided

457 by National Science Foundation Grant EAR 07-25019 (C. Duffy), and EAR 12-39285, EAR 13-

45831726 (S. Brantley) for the Susquehanna Shale Hills Critical Zone Observatory and the

459 Department of Ecosystem Science and Management. 
460

461

462

463

464

465

466

467

468

469

470

471

472

473

474

475

476

\section{7}

478

479

480

481

\section{Literature Cited}

Andrews, D.M., Lin, H., Zhu, Q., Jin, L., and Brantley, S.L. 2011. Hot spots and hot moments of dissolved organic carbon export and soil organic carbon storage in the Shale Hills catchment. Vadose Zone J. 10 (3): 943-954. doi:10.2136/vzj2010.0149.

Barford, C.C., Wofsy, S.C., Goulden, M.L., Munger, J.W., Hammond Pyle, E., Urbanski, S.P., Hutyra, L., Saleska, S.R., Fitzjarrald, D., and Moore, K. 2001. Factors controlling long and short-term sequestration of atmospheric $\mathrm{CO}_{2}$ in a mid-latitude forest. Science. 294 (5547):1699-1691. doi: 10.1126/science.1062962.

Bartuszevige, A.M., Hrenk, R.L., and Gorchov, D.L. 2007. Effects of leaf litter on establishment, growth and survival of invasive plant seedlings in a deciduous forest. Am. Midl. Nat. 158(2): 472-477. doi: 10.1674/0003-0031.

Boerner, R.E.J., and Kooser, J.G. 1989. Leaf litter redistribution among forest patches within an Allegheny Plateau watershed. Landscape Ecol. 2(2): 81-92. doi: 10.1007/BF00137152.

Bowden, R.D., Nadelhoffer, K.J., Boone, R.D., Melillo, J.M., and Garrison, J.B. 1992.

Contributions of aboveground litter, belowground litter, and root respiration to total soil respiration in a temperate mixed hardwood forest. Can. J. Forest Res. 23(7): 1402-1407.

Doi: $10.1139 / \mathrm{x} 93-177$.

Brown, S.L., and Schroeder, P.E. 1999. Spatial patterns of aboveground production and mortality of woody biomass for eastern U.S. forests. Ecol. Appl. 9(3):968-980. Doi: 10.1016/S03781127.

Burns, R.M., and Honkala, B.H. 1990. Silvics of North America: 1.Conifers; 2. Hardwoods. Agricultural Handbook 654, vol 2. US Dept. of Ag. For. Serv., Washington, DC, 877 p. 
482 Chambers, J.Q., dos Santos, J, Ribeiro, R.J., and Higuchi, N. 2001. Tree damage, allometric 483 relationships, and above-ground net primary production in central Amazon forest. Forest 484 Ecology and Management 152: 73-84. Doi: 10.1016/S0378-1127(00)00591-0.

485 Clark, D.A., Brown, S., Kicklighter, D.W., Chambers, J.Q., Thomlinson, J.R., and Ni, J. 2001. 486 Measuring Net Primary Production in Forests: Concepts and Field Methods. Ecol. Appl. 487 488 11(2): 356-370. Doi: 10.2307/3060894.

Curtis, P.S., Hanson, P.J., Bolstad, P., Barford, C., Randolph, J.C., Schmid, H.P., and Wilson, K.B. 2002. Biometeric and eddy-covariance based estimates of annual carbon storage in five eastern North American deciduous forests. Agr. Forest Meteorol. 113 (1): 3-19. Doi: 10.1016/S0168-1923.

493

Eissenstat, D.M, and Kaye, M.W. 2012. CZO Dataset: Shale Hills - Vegetation (2008-2012) Tree Survey. Available from http://criticalzone.org/shale-hills/data/dataset/2648/ [accessed 31 March 2016].

ESRI. 2013. Geostatistical Analyst Tutorial. ArcGIS Desktop: Release 10.2. Redlands, CA: Environmental Systems Research Institute.

497

498

499 500 501 502 503 504

Facelli, J.M., and Pickett, S.T.A. 1991. Indirect effects of litter on woody seedlings subject to herb competition. Oikos. 62(2): 129-138. Doi: 10.2307/3545257.

Fahey, T.J., Siccama, T.G., Driscoll, C.T., Likens, G.E., Campbell, J., Johnson, C.E., Battles, J.J., Aber, J.D., Cole, J.J., Fisk, M.C., Groffman, P.M., Hamburg, S.P., Holmes, R.T., Schwarz, P.A., and Yanai, R.D. 2005. The biogeochemistry of carbon at Hubbard Brook. Biogeochemistry. 75(1): 109-176. Doi: 10.1007/s10533-004-6321-y.

Fahnestock, J.T., Povirk, K.L., and Welker, J.M. 2000. Ecological significance of litter redistribution by wind and snow in arctic landscapes. Ecography. 23(5): 623-631. 
505 Ferrari, J.B., and Sugita, S. 1996. A spatially explicit model of leaf litter fall in hemlock506 hardwood forests. Can. J. Forest Res. 26(11): 1905-1913. Doi: 10.1139/x26-215.

507 Goodale, C.L., Apps, M.J., Birdsey, R.A., Field, C.B., Heath, L.S., Houghton, R.A., Jenkins, 508 J.C., Kohlmaier, G.H., Kurz, W., Liu, S., Nabuurs, G., Nilsson, S., and Shvidenko, A.Z. 509 510 511

Houghton, R.A. 2005. Aboveground forest biomass and the global carbon balance. Global

Holdsworth, A.R., Frelich, L.E., and Reich, P.B. 2012. Leaf litter disappearance in earthworminvaded northern hardwood forests: role of tree species and the chemistry and diversity of litter. Ecosystems. 15(6): 913-926. Doi: 10.1007/s10021-012-9554-y. Change Biol. 11(6): 945-958. Doi: 10.1111/j.1365-2486.2005.00955.x.

Jenkins, J., Chojnacky, D., Heath, L., and Birdsey, R. 2003. National-scale biomass estimators for United States tree species. For. Sci. 49(1): 12-35.

Jenkins, J., Chojnacky, D., Heath, L., and Birdsey, R. 2004. Comprehensive database of diameter-based biomass regressions for North American tree species. USDA Forest Service. Gen. Tech. Rep. NE-319: 1-48.

Jin, L., and Brantley, S.L. 2011. Soil chemistry and shale weathering on a hillslope influenced by 24 convergent hydrologic flow regime at the Susquehanna/Shale Hills Critical Zone 25 Observatory. Applied Geochemistry. 26: 551-556. Doi: 10.1016/j.apgeochem.2011.03.027

26 Kaye, M.W., Smith, L., Eissenstat, D., Wubbles, J., Adams, T., and Osborne, J. 2015. 
Library. doi: 10.1594/IEDA/100516. Available from: http://get.iedadata.org/doi/100516 [accessed on 31 March 2016].

Kreye, J.K., Varner, J.M., Hiers, J.K., and Mola, J. 2013. Toward a mechanism for eastern North American forest mesophication: differential litter drying across 17 species. Ecol. Appl. 23(8): 1976-1986. Doi: 10.1890/13-0503.1.

Lee, D., Yoo, G., Oh, S., Shim, J.H., and Kang, S. 1999. Significance of aspect and understory type to leaf litter redistribution in a temperate hardwood forest. Korean J. Bio. Sci. 3(2): 143147. Doi: $10.1080 / 12265071.1999 .9647477$.

Lin, H.S., Kogelmann, W., Walker, C., and Bruns, M.A. 2006. Soil moisture patterns in a forested catchment: a hydropedological perspective. Geoderma. 131(3): 345-368. Doi: 10.1016/j.geoderma.2005.03.013.

McClaugherty, C.A., Pasto J, Aber JD, and Melillo JM. 1985. Forest litter decomposition in relation to soil nitrogen dynamics and litter quality. Ecology 66(1): 266-275. Doi: $10.2307 / 1941327$

Naithani, K.J., Baldwin, D.C., Gaines, K.P., Lin, H., and Eissenstat, D.M. 2013. Spatial distribution of tree species governs the spatio-temporal interaction of leaf area index and soil moisture across a forested landscape. PLOS ONE 8(3): e58704. Doi: 10.1371/journal.pone.0058704.

Orndorff, K.A., and Lang, G.E. 1981. Leaf litter redistribution in a West Virginia hardwood forest. J. Ecol. 69(1): 225-235. Doi: 10.2307/2259827.

Pregitzer, K.S., and Burton, A.J. 1991. Sugar maple seed production and nitrogen in litter fall. Can. J. Forest Res. 21(7): 1148-1153. 
550 R Developmental Core Team. 2013. R: A language and environment for statistical computing.

551 Vienna, Austria: R Foundation for Statistical Computing. Retrieved from http://www.Rproject.org [accessed 13 October 2013].

553 Richardson, A.D., Hollinger, D.Y., Dail, D.B., Lee, J.T., Munger, J.W., and O’Keefe, J. 2009.

$554 \quad$ Influence of spring phenology on seasonal and annual carbon balance in two contrasting New

555 England forests. Tree Physiol. 29 (3): 321-331. Doi: 10.1093/treephys/tpn040.

556 Sharma, C.M., Gairola, S., Baduni, N.P., Ghildiyal, S.K., and Suyal, S. 2011. Variation in carbon 557 stocks on different slope aspects in seven major forest types of temperate region of Garhwal 558 Himalaya, India. J. Biosci. 36(4): 1-14. Doi: 10.1007/s12038-011-9103-4.

559 Siccama, T.G., Fahey, T.J., Johnson, C.E., Sherry, T.W., Denny, E.G., Girdler, E.B., Likens, 560 G.E., and Schwarz, P.A. 2007. Population and biomass dynamics of trees in a northern 561 562 563 hardwood forest at Hubbard Brook. Can. J. Forest Res. 37(4): 737: 749. Doi: 10.1139/X06261.

Stoy, P.C., Dietze, M.C., Richardson, A.D., Vargas, R., Barr, A.G., Anderson, R.S., Arain, M.A., Baker, I.T., Black, T.A., Chen, J.M., Cook, R.B., Gough, C.M., Grant, R.F., Hollinger, D.Y., Izaurralde, R.C., Kucharik, C.J., Lafleur, P., Law, B.E., Liu, S., Lokupitiya, E., Luo, Y., Munger, J.W., Peng, C., Poulter, B., Price, D.T., Ricciuto, D.M., Riley, W.J., Sahoo, A.K., Schaefer, K., Schwalm, C.R., Tian, H., Verbeek, H., and Weng, E. 2013. Evaluating the agreement between measurements and models of net ecosystem exchange at different times and timescales using wavelet coherence: an example using data from the North American Carbon Program Site-Level Interim Synthesis. Biogeosciences. 10(11): 6893-6909. Doi: 10.5194/bg-10-6893-2013. 
572 Turner, D.P., Koerper, G.J., Harmon, M.E., and Lee, J.J. 1995. Carbon budgets for United States

573 Forests. Ecol. Appl. 5(2): 421-436. Doi: 10.2307/1942033.

574 Waring, R.H., Landsberg, J.J., and Williams, M. 1998. Net primary production of forests: A

575 constant fraction of gross primary production? Tree Physiol. 18(2): 129-134. Doi:

$576 \quad 10.1093 /$ treephys/18.2.129.

577 Way, D.A., and Oren, R. 2010. Differential responses to changes in growth temperature between 578 trees from different functional groups and biomes: a review and synthesis of data. Tree 579 Physiol. 30(6): 669-688. doi: 10.1093/treephys/tpq015

580 Wubbels, J.K. 2010. Tree species distribution in relation to stem hydraulic traits and soil 581 moisture in a mixed hardwood forest in central Pennsylvania. A thesis in horticulture, $582 \quad$ submitted in partial fulfillment at The Pennsylvania State University.

583 Xiong, S., and Nilsson, C. 1999. The effects of plant litter on vegetation: a meta-analysis. J.

$584 \quad$ Ecol. 87: 984-994.

585 Yanai, R.D., Battles, J.J., Richardson, A.D., Blodgett, C.A., Wood, D.M., and Rastetter, E.B.

586 2010. Estimating uncertainty in ecosystem budget calculations. Ecosystems. 13: 239-248.

587 Doi: 10.1007/s10021-010-9315-8.

588 Yanai, R.D., Arthur, M.A., Acker, M., Levine, C.R., and Park, B.B. 2012a. Variation in mass

589 and nutrient concentration of leaf litter across years and sites in a northern hardwood forest.

590 Can. J. Forest Res. 42(8): 1597-1610. Doi: 10.1139/x2012-084.

591 Yanai, R.D., Levine, C.R., Green, M.B., and Campbell, J.L. 2012b. Quantifying Uncertainty in

592 Forest Nutrient Budgets. J. For. 110(8): 448-456. Doi: 10.5849/jof.11-087. 
593 Yousef, Y.A., Hvitved-Jacobsen, T., Wanielista, M.P., and Harper, H.H. 1987. Removal of 594 contaminants in highway runoff flowing through swales. Sci Total Environ. 59: 391-399. 595 Doi: $10.1016 / 0048-9697(87) 90462-1$. 


\section{Tables}

I. Aboveground net primary productivity (ANPP; $\left.\mathrm{gC} \mathrm{m}^{-2} \mathrm{yr}^{-1}\right)$, stem counts, basal area $\left(\mathrm{m}^{2}\right.$ hectare $^{-1}$ ), Aboveground Woody Increment (AGWI; gC m-2 yr ${ }^{-1}$ ), and average 2011 and 2012 leaf litter production $\left(\mathrm{gC} \mathrm{m}-2 \mathrm{yr}^{-1}\right.$ ) for canopy tree species found in the 8.5 ha Susquehanna Shale Hills Critical Zone Observatory watershed.

\begin{tabular}{|c|c|c|c|c|c|}
\hline Species (species code) & $\begin{array}{c}\text { ANPP } \\
\mathrm{gC} \mathrm{m}^{-2} \mathrm{yr}^{-1}\end{array}$ & $\begin{array}{c}\text { \# of } \\
\text { stems }\end{array}$ & $\begin{array}{c}\text { Basal Area } \\
\mathrm{m}^{2} \mathrm{ha}^{-1}\end{array}$ & $\begin{array}{c}\text { AGWI } \\
\mathrm{gC} \mathrm{m}^{-2} \mathrm{yr}^{-1}\end{array}$ & $\begin{array}{l}\text { Leaf Litter } \\
\mathrm{gC} \mathrm{m}^{-2} \mathrm{yr}^{-1}\end{array}$ \\
\hline Quercus rubra (QURU) & 120.4 & 280 & 5.4 & 77.5 & 42.9 \\
\hline Q. prinus (QUPR) & 103.3 & 554 & 6.4 & 69.1 & 34.2 \\
\hline Q. alba (QUAL) & 73.8 & 277 & 3.7 & 47.3 & 26.5 \\
\hline Carya spp.* (CASP) & 59.1 & 333 & 3.2 & 35.2 & 23.9 \\
\hline Acer saccharum (ACSA) & 30.2 & 130 & 1.1 & 9.3 & 20.9 \\
\hline Q. velutina (QUVE) & 17.8 & 47 & 0.88 & 11.3 & 6.5 \\
\hline Tsuga canadensis(TSCA) & 15.5 & 163 & 2.1 & 14.3 & 1.2 \\
\hline Pinus strobus (PIST) & 8.80 & 56 & 0.92 & 6.40 & 2.4 \\
\hline A. rubrum (ACRU) & 3.80 & 20 & 0.23 & 1.77 & 2.03 \\
\hline Fraxinus americana (FRAM) & 3.46 & 33 & 0.30 & 2.36 & 1.1 \\
\hline P.virginiana (PIVI) & 3.12 & 89 & 0.84 & 2.36 & 0.76 \\
\hline Liriodendron tulipifera (LITU) & 1.41 & 13 & 0.19 & 1.33 & 0.08 \\
\hline Fagus grandifolia (FAGR) & 0.900 & 7 & 0.06 & 0.740 & 0.16 \\
\hline Nyssa sylvatica (NYSY) & 0.463 & 4 & 0.04 & 0.053 & 0.41 \\
\hline Magnolia acuminate (MAAC) & 0.391 & 3 & 0.05 & 0.381 & 0.01 \\
\hline Prunus serotina (PRSE) & 0.340 & 5 & 0.04 & 0.200 & 0.14 \\
\hline Betula lenta (BELE) & 0.188 & 10 & 0.07 & 0.158 & 0.03 \\
\hline Tilia americana (TIAM) & 0.156 & 3 & 0.02 & 0.036 & 0.12 \\
\hline P. pungens (PIPU) & 0.101 & 2 & 0.03 & 0.101 & 0.0 \\
\hline B. alleghaniensis (BEAL) & 0.008 & 2 & 0.01 & 0.008 & 0.0 \\
\hline TOTAL & 443.2 & 2031 & 25.4 & 279.8 & 163.4 \\
\hline
\end{tabular}


II. Forest structure and carbon dynamics in the catchment scale, and four topographic positions; south aspect, north aspect, non-swale slopes, and swales. Data from 2031 trees greater than 20$\mathrm{cm}$ diameter in 2008 in the 8.5 ha watershed were included in the analyses.

\begin{tabular}{|c|c|c|c|c|c|}
\hline & Catchment & $\begin{array}{l}\text { South } \\
\text { aspect }\end{array}$ & $\begin{array}{l}\text { North } \\
\text { aspect }\end{array}$ & $\begin{array}{c}\text { Non-swale } \\
\text { slopes }\end{array}$ & Swales \\
\hline No. species & 23 & 20 & 23 & 23 & 16 \\
\hline Area (ha) & 8.53 & 3.85 & 4.68 & 6.64 & 1.89 \\
\hline Tree density (stems ha ${ }^{-1}$ ) & 238.9 & 243.4 & 233.8 & 241.7 & 229.5 \\
\hline Total biomass $\left(\mathrm{kgC} \mathrm{m}^{-2}\right)$ & 9.5 & 9.6 & 9.4 & 9.3 & 10.2 \\
\hline Total basal area $\left(\mathrm{m}^{2} \mathrm{ha}^{-1}\right)$ & 25.4 & 25.6 & 25.3 & 25.3 & 26.2 \\
\hline Total AGWI $\left(\mathrm{gC} \mathrm{m}^{-2} \mathrm{yr}^{-1}\right)$ & 279.8 & 307.8 & 256.9 & 261.4 & 348.8 \\
\hline \multicolumn{6}{|c|}{ Basal area per tree $\left(\mathrm{cm}^{2}\right)(\mathrm{SE})$} \\
\hline & All spp & $1050(19.3)$ & $1081(20.7)$ & $1046(16.2)$ & 1143 (29.9) \\
\hline & QURU & $1464(73.4)$ & 1737 (65.7) & $1576(58.2)$ & $1809(94.0)$ \\
\hline & QUPR & $1063(36.2)$ & $922(25.8)$ & $946(24.3)$ & $1081(44.2)$ \\
\hline & QUAL & $1110(48.0)$ & $1178(69.6)$ & $1159(49.1)$ & $1072(61.5)$ \\
\hline & ACSA & $725(47.2)$ & $733(47.1)$ & $715(33.4)$ & $796(109.2)$ \\
\hline \multicolumn{6}{|c|}{ AGWI per tree $\left(\mathrm{kgC} \mathrm{yr}^{-1}\right)(\mathrm{SE})$} \\
\hline & All spp & $12.6(0.6)$ & $10.9(0.5)$ & $10.8(0.4)$ & $15.2(1.2)$ \\
\hline & QURU & $24(3.3)$ & $23.4(1.7)$ & $22.4(1.6)$ & $26.8(3.8)$ \\
\hline & QUPR & $13.5(1.2)$ & $8.7(0.8)$ & $10.1(0.7)$ & $12.5(1.7)$ \\
\hline & QUAL & $14.7(1.3)$ & 14.2.(1.8) & $14.1(1.0)$ & $15.9(3.1)$ \\
\hline & ACSA & $4.7(0.7)$ & $4.5(0.7)$ & $4.4(0.6)$ & $5.3(1.0)$ \\
\hline
\end{tabular}

Note. Aboveground wood increment (AGWI) represents average annual wood C gain from 2008 to 2012. Average basal area and AGWI (per tree) with standard errors are provided for each topographic position for all species combined and for the four dominant species in the catchment. Values in bold represent significant differences between aspects (non-swale vs. swale) or slopes (south vs. north) at $\alpha=0.05$. See Table 1 for species codes. 


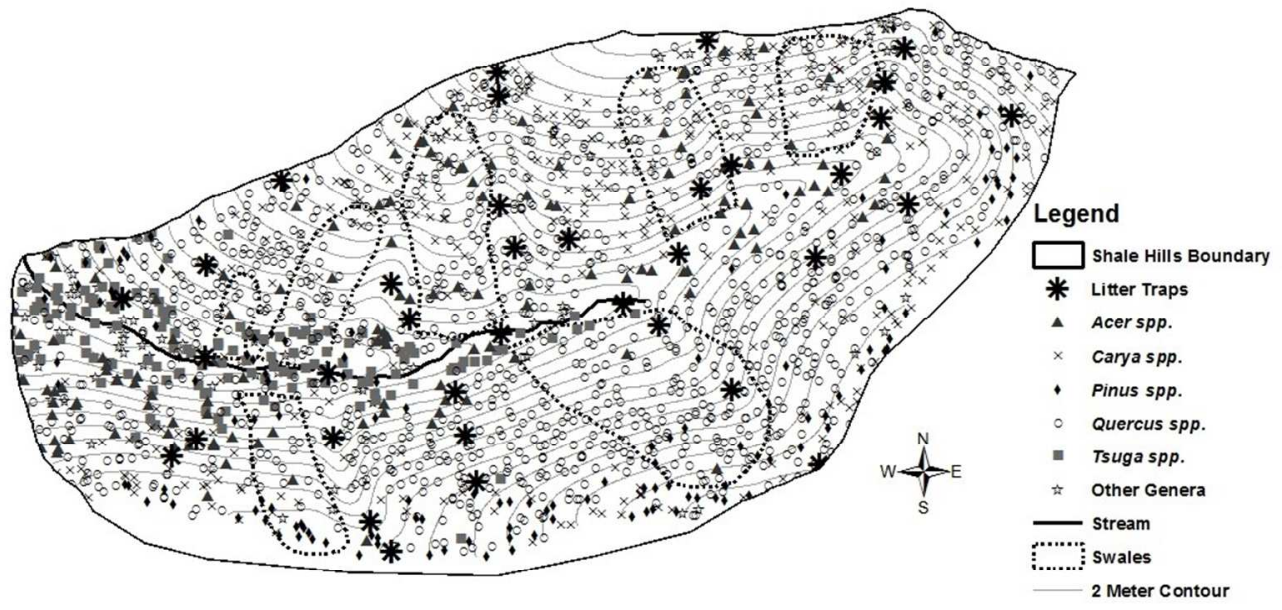

Figure 1. The Susquehanna Shale Hills Critical Zone Observatory with distribution of the five main tree genera. Each point represents one tree from one of the five main genera (Acer spp., Carya spp., Pinus spp., Quercus spp., and Tsuga spp.) or other genera. Dashed areas represent low-lying swales and stars indicate litter trap locations.

Fig. 1

$279 \times 215 \mathrm{~mm}(96 \times 96 \mathrm{DPI})$ 


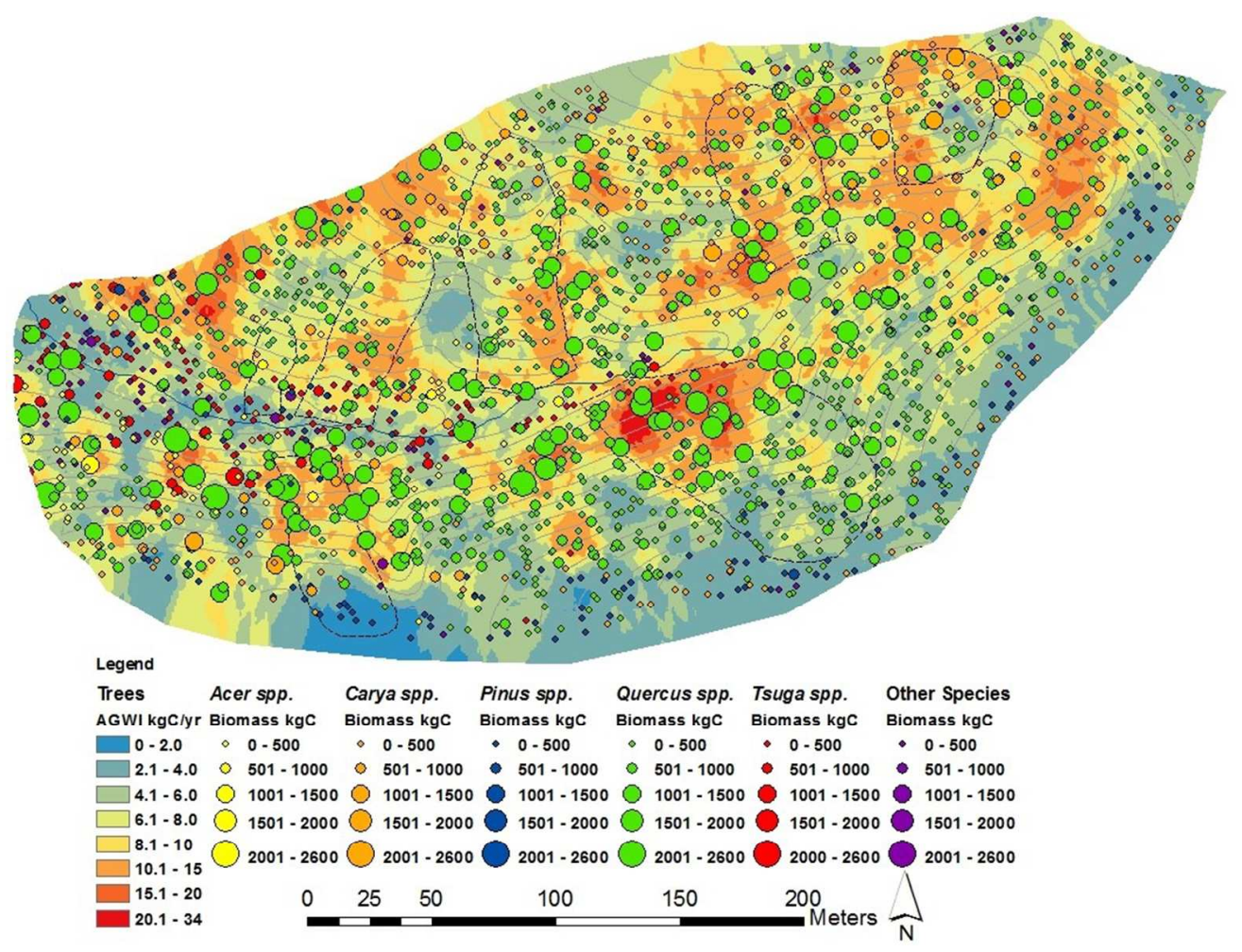

Figure 2. Tree woody biomass $(\mathrm{kg})$ and average annual aboveground woody increment (AGWI) (gC yr-1) at the Susquehanna Shale Hills Critical Zone Observatory in 2012 . Trees $>20 \mathrm{~cm}$ in 2008 were measured for analysis. Each point represents one tree. Point size and color indicate total woody biomass and genera, respectively. Areas of high AGWI in the watershed are colored in red and areas of low AGWI are colored in blue.

Fig. 2

$279 \times 215 \mathrm{~mm}(96 \times 96 \mathrm{DPI})$ 


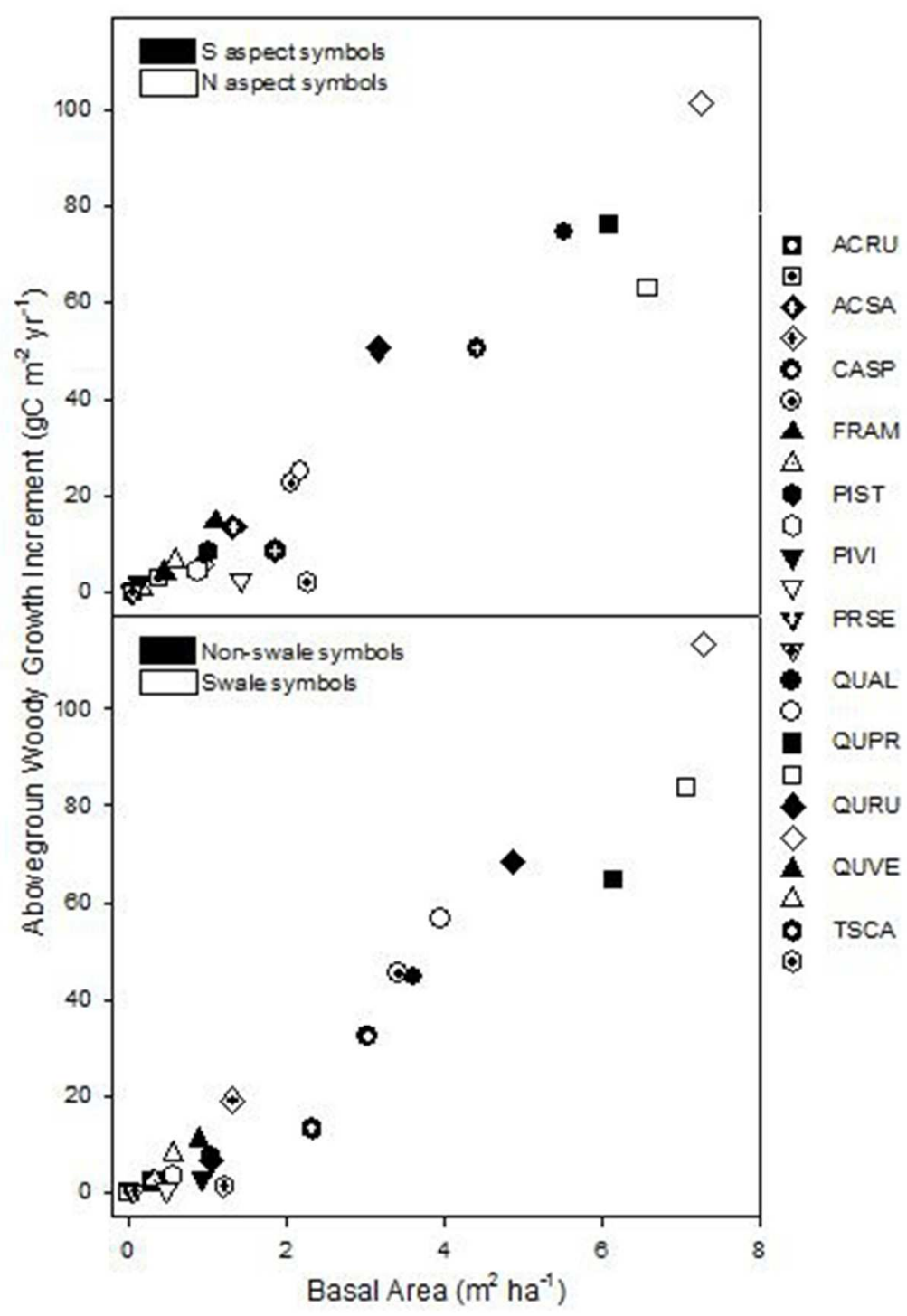

Figure 3. Basal area (BA) in $\mathrm{m} 2$ hectare-1 yr-1 of 11 tree species and one genus (Carya) in the SSHCZO watershed by aboveground woody increment (AGWI) in $\mathrm{gC} \mathrm{m-2} \mathrm{yr-1.} \mathrm{Top} \mathrm{panel} \mathrm{compares} \mathrm{BA} \mathrm{and} \mathrm{AGWI} \mathrm{for}$ each species on south $(\mathrm{S})$ and north $(\mathrm{N})$ aspects and bottom panel compares values on non-swale slopes and swales. See Table 1 for species codes.

Fig. 3

$103 \times 148 \mathrm{~mm}(96 \times 96$ DPI) 


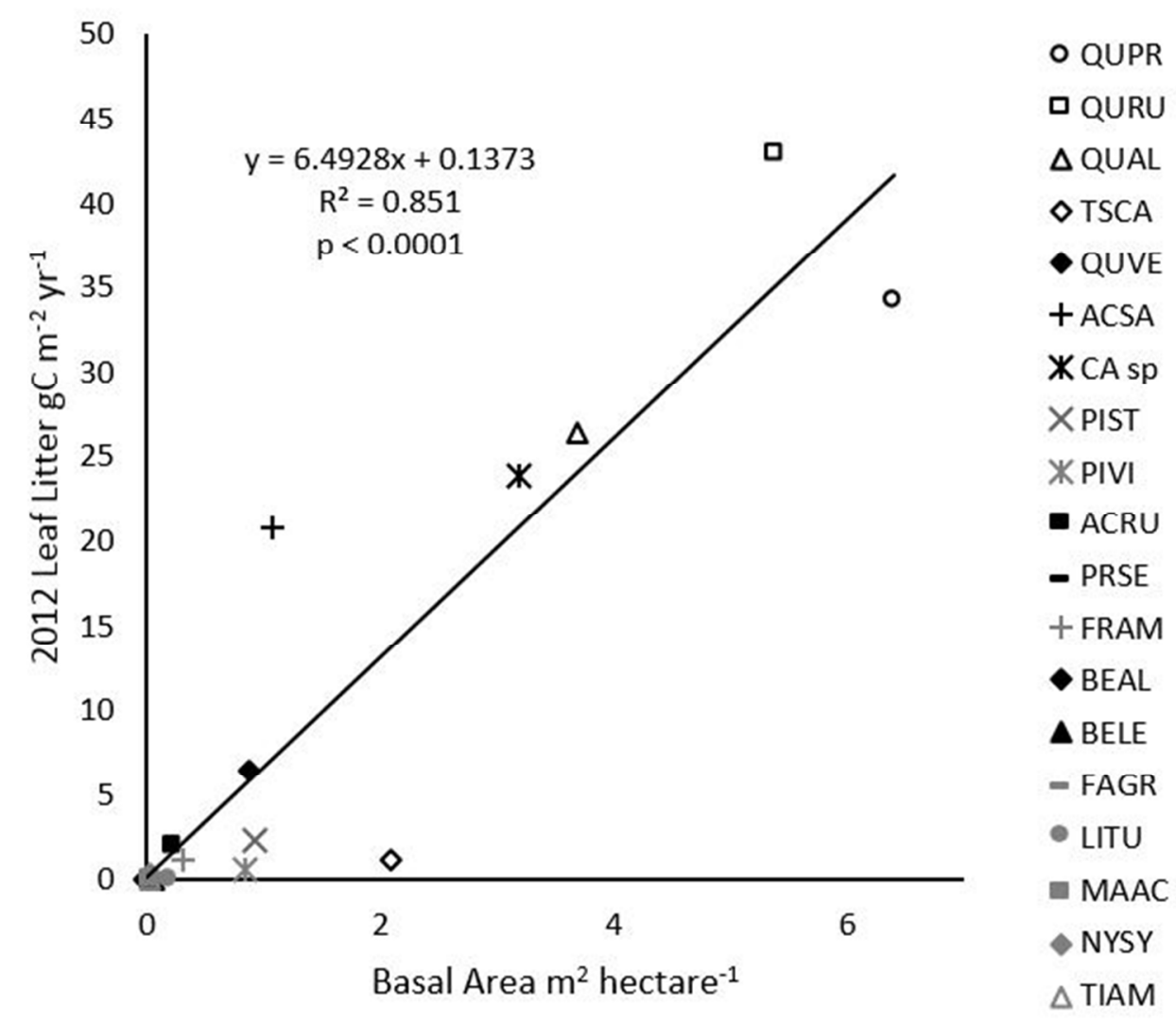

Figure 4. The relationship of basal area ( $\mathrm{m} 2$ ha-1) of 19 tree species with the total amount of leaf litter in gC $m-2$ collected in the litter traps ( $n=35$ litter traps) during 2011 and 2012. Each point represents one species, except CA sp. represents sum of four Carya species. Species are listed in the order of dominance (i.e. the greatest woody biomass) in the watershed. See Table 1 for species codes.

Fig. 4

$167 \times 142 \mathrm{~mm}(96 \times 96$ DPI $)$ 


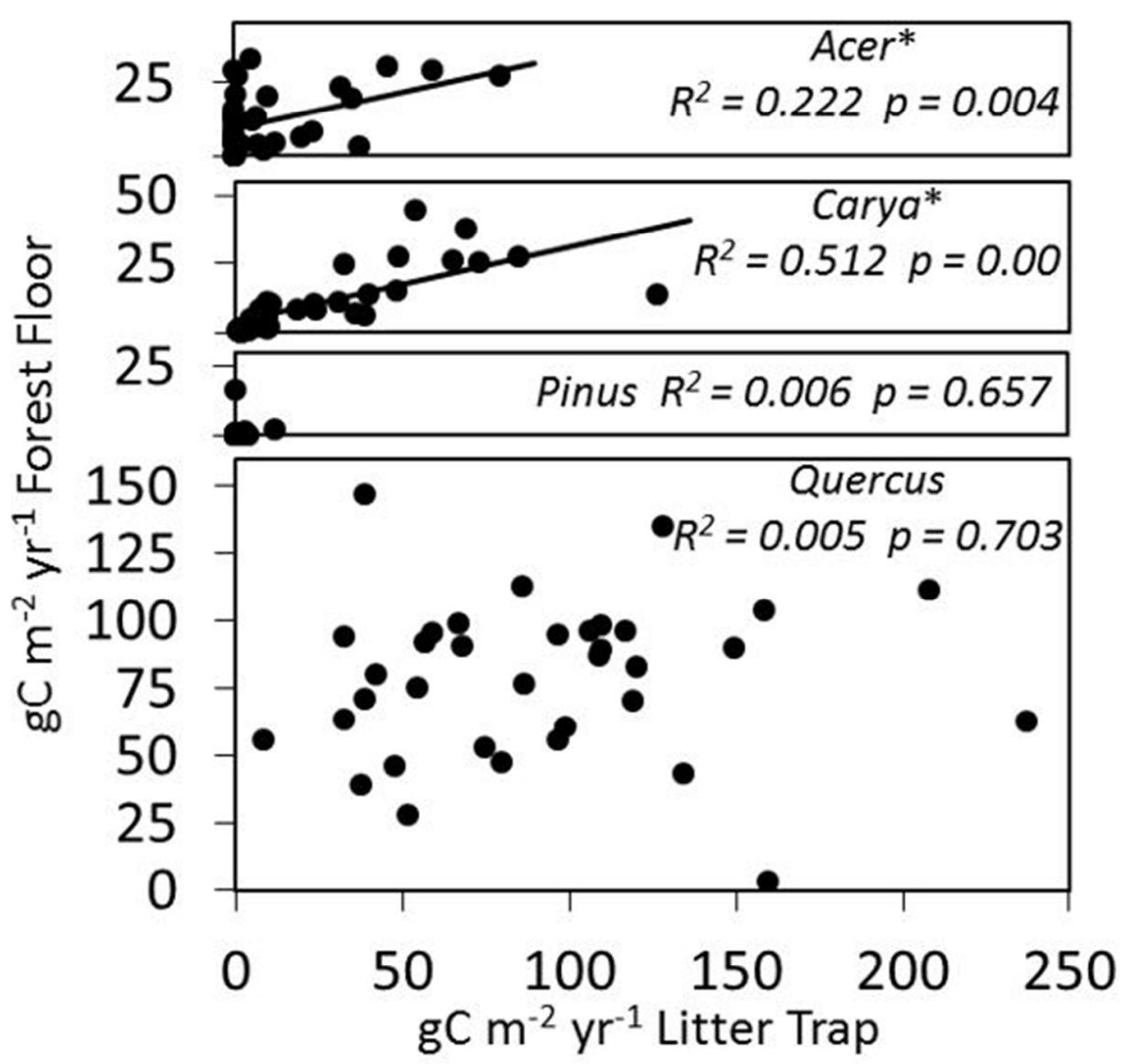

Figure 5. Comparisons of leaf litter in raised traps with that found on the forest floor of four genera (Acer, Carya, Pinus, Quercus) at Shale Hills ( $\mathrm{df}=34, \mathrm{~N}=35$ locations). Stars denote linear relationships with slopes different from zero $(P<0.05)$.

Fig. 5

$161 \times 148 \mathrm{~mm}(96 \times 96 \mathrm{DPI})$ 


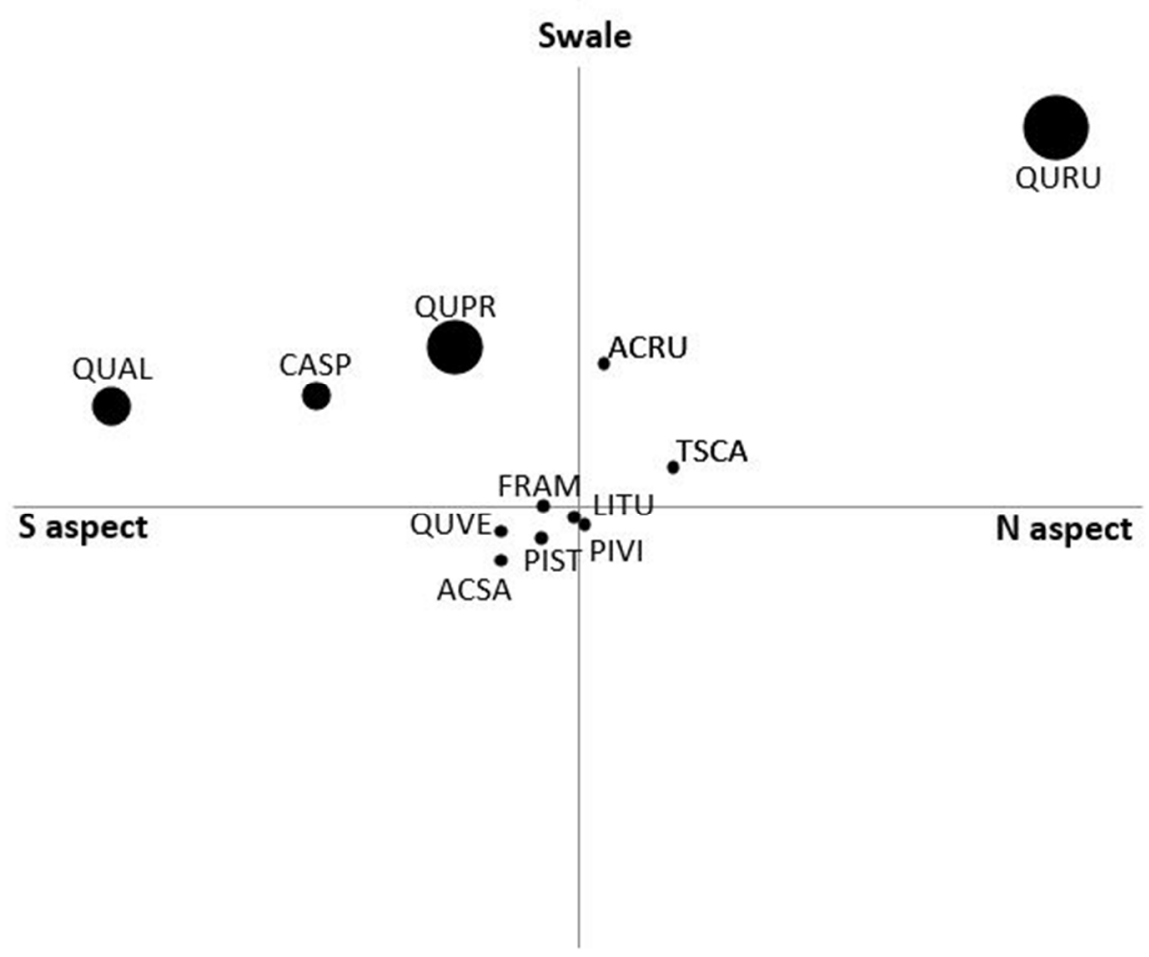

Non-swale

Figure 6. Comparison of species productivity on four topographic positions: south and north aspects, swales, and non-swale slopes. Size of black circles represents the species aboveground standing biomass (e.g. Q. prinus and Q. rubra have highest biomasses in the watershed, Table 1). Location of black circles calculated by the difference of species' AGWI between south and north aspect (horizontal axis) and swales and nonswale slopes (vertical axis) (Table 3). Twelve species with the highest biomass in the watershed were included. See Table 1 for species codes.

Fig. 6

$178 \times 142 \mathrm{~mm}(96 \times 96 \mathrm{DPI})$ 